\title{
The Development of Modern Business
}




\section{The Development of Modern Business}

Gordon Boyce

and

Simon Ville 


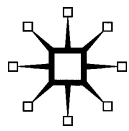

(c) Gordon Boyce and Simon Ville 2002

All rights reserved. No reproduction, copy or transmission of this publication may be made without written permission.

No paragraph of this publication may be reproduced, copied or transmitted save with written permission or in accordance with the provisions of the Copyright, Designs and Patents Act 1988, or under the terms of any licence permitting limited copying issued by the Copyright Licensing Agency, 90 Tottenham Court Road, London W1T 4LP.

Any person who does any unauthorised act in relation to this publication may be liable to criminal prosecution and civil claims for damages.

The authors have asserted their rights to be identified as the authors of this work in accordance with the Copyright, Designs and Patents Act 1988.

First published 2002 by

PALGRAVE

Houndmills, Basingstoke, Hampshire RG21 6XS and 175 Fifth Avenue, New York, N.Y. 10010

Companies and representatives throughout the world

PALGRAVE is the new global academic imprint of

St. Martin's Press LLC Scholarly and Reference Division and

Palgrave Publishers Ltd (formerly Macmillan Press Ltd).

ISBN 978-0-333-59877-1 hardback

ISBN 978-0-333-59878-8 ISBN 978-1-137-12008-3 (eBook)

DOI 10.1007/978-1-137-12008-3

This book is printed on paper suitable for recycling and made from fully managed and sustained forest sources.

A catalogue record for this book is available from the British Library.

Library of Congress Cataloging-in-Publication Data

Boyce, Gordon, 1954-

The development of modern business / Gordon Boyce and Simon Ville.

p. $\mathrm{cm}$.

Includes bibliographical references and index.

ISBN 978-0-333-59877-1 (cloth) - ISBN 978-0-333-59878-8 (pbk.)

1. Business - History. 2. Corporation - Growth - History. 3. Industrial organization - History. 4. Big business - History. 5. Industries - Great Britain - History. 6. Industries - United States - History. 7. Industries Japan - History. 8. Industries - Australia - History. I. Ville, Simon P.

II. Title.

HF499 .B65 2001

$338.7^{\prime} 09-\mathrm{dc} 21$

2001045865

$\begin{array}{llllllllll}10 & 9 & 8 & 7 & 6 & 5 & 4 & 3 & 2 & 1\end{array}$

$\begin{array}{llllllllll}11 & 10 & 09 & 08 & 07 & 06 & 05 & 04 & 03 & 02\end{array}$


For Charlotte Erickson and Robin Craig 


\section{Contents}

List of Boxes, Documents, Tables and Figures viii

List of Plates xii

Preface xiii

Acknowledgements xvi

1 History and Theory of the Growth of the Firm 1

2 Entrepreneurship and Management 29

3 Information and Uncertainty 56

4 Corporate Finance $\quad 84$

5 Labour Management $\quad 116$

6 Production 145

$\begin{array}{lll}7 & \text { Marketing } & 175\end{array}$

$\begin{array}{lll}8 & \text { Structure } & 227\end{array}$

9 Interorganisational Relations and Cooperative Structures $\quad 260$

10 International Business 289

11 Government and Business 314

12 The Development of Modern Business: A Summary and Prospective $\quad 342$

Bibliography $\quad 349$

Index 368 


\section{List of Boxes, Documents,}

Tables and Figures

\section{Boxes}

2.1 Josiah Wedgwood 47

2.2 Engineers and the rise of professional managers in Japan 50

2.3 Robert Campbell - entrepreneurship under conditions of uncertainty

3.1 The new office: technological change in the corporation at the turn of the twentieth century

3.2 The Holt-Swire-Scott network's decision-support system, 1860-1970

3.3 Lyons' 'teashop' computer and IBM

4.1 The development of British corporate law: limited liability and the legal personality of the firm

4.2 Australian pastoral agents: networking and specialist financial intermediation

4.3 The London Stock Exchange

4.4 Company promoters as intermediaries: J. P. Morgan vs Sir Ernest T. Hooley

5.1 White's of Sunderland and industrial paternalism 134

5.2 Cadbury's use of scientific management 136

5.3 Thomson's profit-sharing scheme, 1886-1921 137

5.4 Matsushita: pioneers in changing labour practices 139

6.1 Carnegie: exploiting economies of scale 165

6.2 Charles Schwab, Judge Gary and oligopolistic competition 166

$\begin{array}{ll}6.3 \text { Du Pont's accounting system } & 168\end{array}$

6.4 Just-in-time at Toyota 170

7.1 Challenging dominant firms: General Motors and Rowntree

7.2 The J. Walter Thompson Company: compounding intangible assets 
7.3 Franchising: a symbiotic relationship between large and small-scale business

8.1 American railroads: pioneers of modern business organisation

8.2 General Motors' innovation in accounting system design

8.3 Dofasco Inc. managing corporate capabilities to accommodate strategic change

9.1 The Steel Manufacturers' Nickel Syndicate, 1901-39

9.2 The Western Mining Corporation - Hanna/Homestead joint venture: game theory applied

9.3 Film-makers' networks

10.1 Imperial Tobacco vs American Tobacco

10.2 The movement of American automobile companies to Europe

10.3 Coca-Cola

10.4 Mitsubishi overseas

11.1 The Associated Northern Collieries and the Australian Industries Preservation Act

11.2 Government investigations into the Titanic disaster

11.3 Government encouragement of the Japanese computer industry

\section{Documents}

2.1 Statement by Sir Frederick W. Lewis, 11 August 1919

2.2 Leonard Cripps' management philosophy, 1933

$\begin{array}{lll}3.1 & \text { Telegraph codes } & 79\end{array}$

3.2 Computerising John Brown \& Co.'s accounts 80

3.3 A contract between John Swire \& Sons and Scott's Shipbuilding \& Engineering Co.

3.4 The Curtis-Pigott correspondence $\quad 81$

4.1 Prospectuses 108

4.2 John Swire's 'private' prospectuses to potential investors in the Taikoo Sugar Refinery, 1881

4.3 Ray Kroc's contract for selling McDonald's franchises 114

4.4 Comments on company prospectuses 115

5.1 Rules for employees of a merchant and ships' chandlers (i.e., provisioning and supply) business, 1852

5.2 Office rules for lady typewriters and clerks, c. 1900

5.3 Personnel management practices 142

5.4 Internal labour markets 143

5.5 Alfred Booth \& Co.'s profit-sharing plan, 1871

6.1 Frederick W. Taylor's 'The Principles of Scientific Management'

6.2 The development of cost-control systems 172

6.3 The Cargo Fleet Iron Co.'s cost structure, 1903 
7.1 Correspondence between Lord Leverhulme and F.A.

Countway

200

7.2 Huntley \& Palmer's ledgers, 1899-1913 202

7.3 Media plan for Pond's, 1956

7.4 The J. Walter Thompson Company's market survey for Meccano, 1960

204

8.1 Excerpts from Sir Stephen Furness' trip reports 252

8.2 Wright Stephenson 'Organisation of Our Business' internal report, 20 November 1906

253

8.3 The organisational structure of Colonial Sugar Refining Company Limited

8.4 Sir Walter Scott, 'Some Remarks on the Commercial Organisation of Shipyards'

8.5 Dofasco's organisational chart, 1952

9.1 Interfirm agreement of Australian Estates, Goldsbrough Mort, and Australian Mercantile Loan and Finance Company, 1930

9.2 Sharing the risk of technical innovation, Lyle and Lithgow

9.3 An example of a cost-driven need to generate inter-firm cooperation

9.4 The J. Walter Thompson Company's 'client histories' 288

10.1 Pinchin Johnson-Swire correspondence 312

10.2 The benefits of multinationals - Frederick Dalgety 312

10.3 Informal methods of control in international business: Curtis's licensing pyramid revisited

11.1 The Pharmaceutical Society of Australasia (PSA) and the professionalisation of the pharmacist in Victoria

11.2 The British Government's investment in Cunard-White Star

11.3 Standard Oil and American Tobacco anti-trust judgements

\section{Tables}

1.1 Total asset valuation of leading 25 firms 9

1.2 Diversification 13

3.1 Railways in operation 66

3.2 Percentage of world fleet owned by leading shipping nations

$\begin{array}{lll}7.1 & \text { Population } & 180\end{array}$

7.2 Growth rates of real GDP 180

7.3 Car ownership 184

7.4 Radio and television ownership 193

10.1 Principal home economies of FDI stocks 293

10.2 Principal host regions of FDI stocks 294

10.3 Sectoral distribution of FDI stocks 294 


\section{Figures}

1.1 Growth and development of the firm 2

1.2 Transaction-cost variables 18

$\begin{array}{lll}1.3 & \text { Transacting frameworks } & 19\end{array}$

$\begin{array}{ll}1.4 & \text { Open systems approach } \\ 1.5 & 20\end{array}$

1.5 Contractual relationships 25

3.1 Transport and communications development 60

4.1 Diagram of the markets on the floor of the London Stock Exchange 'House' 105

8.1 Traditional form of organisational structure 231

8.2 Unitary (U-form) organisational structure 234

8.3 Holding company/zaibatsu 238

8.4 Multidivisional (M-form) organisational structure 241

8.5 Matrix organisational structure $\quad 245$

9.1 Spectrum of transacting frameworks 263

9.2 Independent film-making networks 283 


\section{List of Plates}

1 Gladstone Pottery Museum 48

2 New Lanark, textile mill 121

3 Co-op store, Styal village $\quad 182$

4 Impulse T-shirt 206

5 Lux: a new way to wash ... 207

6 Lux: the things you'd never put... 208

7 Lux: save more things 209

8 Lifebuoy all's well 210

9 Globe metal polish 211

10 Lux: Savon de toilette $\quad 212$

11 Pears 213

12 Close up before you consider 214

13 US playing card. Quick! which is the enemy? 215

14 Off with the old, on with the new 216

15 Lux: I wanted to be lovely 217

16 Lux: date appeal 218

17 Lux: Hollywood's beauty care 219

18 Close-up 220

19 Romance is back 221

20 Lux: now Hollywood's own beauty soap 222

21 Lux: vote today 223

22 Impulse: your customers are acting on impulse 224

23 PO-KE-NO 225

24 Titanic 226 


\section{Preface}

We have written this book for the benefit of university undergraduates who, with a basic background in economics or management, are approaching the study of business history for the first time. It examines the development of modern business over the last two centuries in Britain, the USA, Japan and Australia. The book synthesises the different theoretical paradigms used in business history, which it then extends supported by a wide range of empirical evidence from all four nations. It begins with a broad historical survey of business growth over the last two centuries and explains the paradigms most useful to its historical analysis. The book is then divided into a series of broad thematic chapters, each dealing with a particular central issue for modern business notably entrepreneurship, information, finance, labour management, production, marketing, organisational structure, interfirm cooperation, international business and government relations. Secondary themes are then addressed within and between chapters such as research and development, business cycles, and corporate responsibilities and ethics. Each chapter follows a standard format. It begins by looking at current issues related to the main theme, and then explains the theoretical tools used to study it. This approach is then applied to survey the experience of the past two centuries finishing close to the present. Greater historical detail is provided by case studies or Boxes and is illuminated further by the inclusion of facsimile original Documents. The Boxes and Documents are located at the end of the chapter to which they relate and are also linked laterally to others appearing in different chapters. Plates 1-3 are located near their reference point in the text; Plates 4-24 are located at the end of Chapter 7. Further material will appear in a web site.

The study of four nations provides sufficient basis for cross-country comparisons without too much dissipation and dilution of detail. The nations chosen we believe provide interesting similarities and differences that help us to distinguish the role of particular environmental factors in business development. Most obviously the four nations are found in different parts of the world and raise the question of the importance of distance and location 
to business enterprise. Factors of production provide both similarities and differences among the four nations. Australia and America would be classified as land-abundant but Japan and Britain as land-scarce. In the nineteenth century Japan and Britain would have been labour-abundant and Australia and America labour-scarce; in the twentieth century America has joined the former group. Each has gone through a distinct modernisation process, Britain as the first industrialiser from the end of the eighteenth century, America caught up a century later through large efficient firms with modern technologies. Japanese industrialisation came in the twentieth century particularly in the postwar economic miracle. Australia has been a developmental outlier, achieving high levels of economic growth in a primary producing economy. Cultural comparisons are also worth investigating. American individualism is often contrasted with Japanese faith in collective behaviour. Individualism has been overlain with group behaviour in a British class system and an Australian frontier survival mentality. Political systems have embodied similar democratic beliefs in the four countries although governmentbusiness relations have been quite different in each case as we shall see.

The approach adopted by this book is unique for the study of modern business history. Some studies exist for individual countries particularly those by Jeremy (1998), Wilson (1995), Hirschmeier and Yui (1975), Bryant and Dethloff (1990) and Fruin (1992). There are several of varying lengths that compare nations including the works of Chandler (1990), Blackford (1988), Schmitz (1993) and McCraw (1997). None however, favour our approach, which can be summarised as using theoretical paradigms and key themes to study the development of modern business in nations offering comparisons and contrasts, and supported by plentiful case studies and original documentation. The book is of a length that provides manageable weekly introductions for students as a starting point for more extended in-depth reading from the list at the end of each chapter.

The title The Development of Modern Business conveys the idea that this is a study of how enterprises have evolved over time to the point where they stand today. This does not imply that there is such a thing as a 'typical firm', nor a singular process of corporate growth. The rise of large numbers of global firms, the clarification of corporations law, and the bureaucratisation of the large business organisation are examples of modern development. However, continual improvement over modern history is not to be inferred. Firms develop through interaction with their environment: eighteenth-century firms were as appropriately designed as those of the twentieth century. In addition, development can also be 'circular' and 'revivalist': for example, the business network of the eighteenth century has re-emerged in a modified form today.

We are grateful to many organisations that allowed us to use their documents and advertisements. We thank Dofasco Inc., United States Playing Card Co., Unilever plc, Unilever US Inc., Furness Withy \& Co. Ltd, John Swire \& Sons Ltd., the Business Records Centre at the University of Glasgow, the History of Advertising Trust in Raveningham Norfolk, the University of Liverpool, the State Library in Melbourne, the Fletcher Challenge Archives Centre at the University of Melbourne, the Noel Butlin Archives Centre at 
the Australian National University, the National Maritime Museum in Greenwich, and the School of Oriental and African Studies in London.

In writing this book we have benefited from the critical comments of a number of colleagues, particularly John Singleton and Steve Jones as well as three referees nominated by Palgrave. Students in our business history groups have wittingly and unwittingly provided us with feedback and inspiration to tackle this work. Terka Acton at Palgrave has been patient with us as the pressures of work led to several deadlines passing. Paola Grinnion and Robert Hood kindly provided assistance with the proofs, index and graphics. Written by two friends, this book is jointly dedicated to two other mutual friends: our PhD supervisers, Charlotte Erickson and Robin Craig, who guided us in the right directions during the early stages of our careers and from whom we have learned a great deal.

The book will be supported by a website that will regularly update material in the book, with new examples and discussions of recent developments in the business history literature:

www.uow.edu.au/commerce/econ/modbusiness

Gordon Boyce Simon Ville 


\section{Acknowledgements}

The authors and publishers wish to thank the following for permission to use copyright material:

The Hartman Center for Sales, Advertising \& Marketing History, Duke University, for permission to use the 'Ponds - 1956' advertising media plan.

The History of Advertising Trust Archive for the use of JWT's marketing plan for Meccano.

Unilever plc for the use of extracts from Lord Leverhulme's business correspondence. Reproduced by kind permission of Unilever plc from originals in Unilever Historical Archives.

Unilever Home \& Personal Care - USA for the use of advertisements from the J. Walter Thompson Collection, including: Lifebuoy 'All's well' 1903, Impulse T-shirt promotion 1980s, LUX 'Your silk stockings, chamois gloves, spats, white glacé shoes' 1920s, 'Save more things with LUX!' Second World War, 'A new way to wash sweaters and sportcoats' 1910s, Savon de Toilette LUX' 1920s, two examples of art deco illustrations used in LUX ads 1930s, 'I wanted to be lovely like Carol Lombard' 1940s, 'Now Hollywood's own beauty soap in a new bath size', 1950s, 'Want to be a girl with date appeal'? 1940s, 'CLOSE-UP was made for whiter teeth and fresh breath' 1980s, 'Romance is back' 1980s, 'CLOSE-UP - Before you consider that flashy feathered fedora, consider your toothpaste', 'Your customers are acting on IMPULSE' 1970s, 'Vote today' 1950s, 'Lux - The things you'd never put in the family laundry', as well as 'Pears Soap'.

The United States Playing Card Company for the use of selected advertisements, including: 'Off with the old, on with the new', 'Quick! which is the enemy' and 'PO-KE-NO'.

Arthur Thomas for 'Diagram of the London Stock Exchange'.

Every effort has been made to trace all the copyright-holders, but if any have been inadvertently overlooked the publishers will be pleased to make the necessary arrangement at the first opportunity. 